\title{
Clinical and microbiological evaluation of 46 episodes of genital ulceration
}

\author{
A W STURM,* G J STOLTING, $\uparrow$ R H CORMANE, $\uparrow$ AND H C ZANEN* \\ Departments of *Medical Microbiology and †Dermatovenereology, University of Amsterdam, Amsterdam, \\ the Netherlands
}

SUMMARY In 44 consecutive patients 46 episodes of genital ulceration were studied. The presumptive clinical diagnosis was evaluated by extensive microbiological investigations. In 15 (33\%) episodes the clinical diagnosis did not accord with the microbiological one. Chancroidal lesions were most commonly found to have other microbiological aetiology. Secondary invasion of treponemal or viral lesions by other bacterial species (mostly anaerobes or pyogenic cocci) or genital pyodermia were the cause of confusion in six of nine cases of chancroid. In the other three a ducreyilike bacterium was found. Direct Gram staining of ulcer material did not help the diagnosis of chancroid. The implications of the results of this study for clinical practice are discussed.

\section{Introduction}

Current textbooks on infectious diseases, ${ }^{1}$ venereology, ${ }^{2}$ and dermatology ${ }^{3}$ emphasise the fact that the diagnosis of genital ulcers is made mainly on their clinical picture and by the exclusion of primary syphilis. There are, however, reports of confusing clinical presentations ${ }^{46}$ and mixed infections. ${ }^{7}$

The aim of this study was to correlate the presumptive clinical diagnosis and the clinical variables with the results of extensive microbiological investigations.

\section{Patients and methods}

\section{PATIENTS}

We studied all 44 patients ( 39 men, five women; aged 20 to 46 (mean 31 ) years) presenting with genital lesions at the department for sexually transmitted diseases (STD) of the Binnen Gasthuis, Amsterdam, in February, March, and April 1978. Of the 39 men, 22 were of north European, nine of West Indian, and eight of Mediterranean origin. Of the five women, four were north European and one Mediterranean. Two patients, both of Mediterranean origin, suffered from a second episode of penile ulceration during the study. Thus we evaluated 46 episodes.

We noted the possible source and date of infection and any history of STD, the number, size, features, and sites of the ulcers, and whether there was inguinal

Address for reprints: Dr A W Sturm, Department of Medical Microbiology, St Laurentius Hospital, Postbox 920, 6040 AX Roermond, the Netherlands.

Accepted for publication 26 August 1986 lymphadenopathy. Patients were examined by two of us (GJS and AWS), and a clinical diagnosis based on current criteria $^{1-3}$ was made after discussion.

\section{COLLECTION OF SPECIMENS}

After their first visit, patients were instructed to keep their lesions moist overnight with saline soaked gauze. The next morning the ulcers were cleaned and, after smears for Gram and Giemsa staining had been made, four specimens were taken with dry calcium alginate swabs, two of which were stabbed into Stuart's transport medium ${ }^{8}$ for bacteriological analysis, one in skimmed milk with penicillin and streptomycin for virological studies, and one in Hanks' balanced salt solution supplemented with glucose for culture for chlamydiae. Finally, after being cleaned again with gauze soaked in ether, the ulcer base was scraped with the flat end of a vaccinostyle to collect exudate for dark field examination. Blood was collected for serological tests, which were repeated six weeks later.

\section{LABORATORY INVESTIGATIONS}

To isolate Haemophilus ducreyi we used one $30 \%$ rabbit blood agar slant and two plates, one incubated in a candle extinction jar with moistened air and one in an anaerobic jar (Gaspak, BBL), both at $33^{\circ} \mathrm{C} .{ }^{9}$ We used New York City medium with and without antibiotics to detect Neisseria gonorrhoeae. ${ }^{10}$ Cultures for other bacterial species were made on $7 \%$ horse blood 
chocolate agar and $5 \%$ sheep blood agar with nalidixic acid $(10 \mathrm{mg} / \mathrm{l})$ in a candle extinction jar, $7 \%$ horse blood agar and CLED medium (containing cysteine and lactose but deficient in electrolytes) (Brolacin agar, Merck) under aerobic conditions, and an anaerobically incubated $7 \%$ horse blood agar plate with gentamicin $(10 \mathrm{mg} / \mathrm{l})$. These were all incubated at $37^{\circ} \mathrm{C}$.

Yeasts were sought on Sabouraud gentamicin agar at $22^{\circ}$ and $37^{\circ} \mathrm{C}$. Genital mycoplasmas were isolated in mycoplasma broth (Difco) and Shepard U9 medium. ${ }^{11}$

Virological studies were performed on human fetal lung fibroblasts and Vero cells. Chlamydiae were cultured in HELA 229 cells pretreated with diethylaminoethanol (DEAE) dextran.

For the serological diagnosis of syphilis we used the Venereal Disease Research Laboratory (VDRL) test, the Kolmer complement fixation test (CFT), and the fluorescent treponemal antibody absorbed (FTAABS) test. Positive reactions were confirmed with the Treponema pallidum immobilisation (TPI) test. Lymphogranuloma venereum antibodies were detected with a complement fixation test. The metabolic inhibition test was performed to measure antibodies to Ureaplasma urealyticum,,$^{12}$ and a growth inhibition test for antibodies to Mycoplasma hominis. ${ }^{13}$

$H$ ducreyi was presumptively identified from typical colonial morphology on microscopy, 5 and identification was confirmed by methods published previously. ${ }^{14}$ Other microbial species were identified by standard methods. ${ }^{15} 16$

\section{Results}

Table I summarises the clinical features of the 46 episodes of genital ulceration. Five of the patients had histories of genital ulcers, and nine gave a history of urethral discharge .The incubation period (calculated as the time from the possible causal sexual contact to the appearance of the ulcer) varied from two days to more than one month. In $25(57 \%)$ of the patients it was less than seven days, and in $37(84 \%)$ it was seven to 14 days. Incubation periods of less than five days were only documented in four patients yielding $H d u c r e y i$ and two patients with pyogenic cocci. Each patient had an average of two (range one to 10) ulcers. There was no relation between the number of ulcers and the culture results.

Table II compares the clinical diagnoses with the results of the microbiological investigations. Chancroid was diagnosed in 19 cases. Based on presumptive identification, $H$ ducreyi, was first thought to have been isolated from 15 of them. Five of these strains, however, were subsequently shown not to belong to this species and are described as ducreyi-

TABLE I Clinical features of and microbiological findings in 46 episodes of genital ulceration

\begin{tabular}{|c|c|c|c|c|c|c|c|c|c|}
\hline \multirow[b]{2}{*}{$\begin{array}{l}\text { Clinical } \\
\text { feature }\end{array}$} & \multicolumn{9}{|c|}{ Microbiological finding } \\
\hline & $\begin{array}{l}H D \\
(n=9)\end{array}$ & $\begin{array}{l}D L \\
(n=3)\end{array}$ & $\begin{array}{l}T P \\
(n=10)\end{array}$ & $\begin{array}{l}T P+ \\
H D / D L \\
(n=3)\end{array}$ & $\begin{array}{l}H S V \\
(n=7)\end{array}$ & $\begin{array}{l}V V \\
(n=1)\end{array}$ & $\begin{array}{l}U U \\
(n=1)\end{array}$ & $\begin{array}{l}P C \\
(n=4)\end{array}$ & $\begin{array}{l}\text { Nil } \\
(n=8)\end{array}$ \\
\hline Acquired from prostitutes & 7 & 1 & 1 & 1 & 1 & 1 & & 4 & 1 \\
\hline Single ulcer & 5 & 2 & 7 & 2 & 2 & & & 3 & $i$ \\
\hline \multicolumn{10}{|l|}{ Ulcer size: } \\
\hline $\begin{array}{l}0.5-2 \mathrm{~cm} \\
>2 \mathrm{~cm}\end{array}$ & $\begin{array}{l}2 \\
5\end{array}$ & 2 & $\begin{array}{l}7 \\
1\end{array}$ & 2 & 1 & 1 & & 3 & 2 \\
\hline $\begin{array}{l}\text { Smooth base } \\
\text { Indurated }\end{array}$ & 9 & 3 & $\begin{array}{l}3 \\
7\end{array}$ & $\begin{array}{l}1 \\
2\end{array}$ & 6 & 1 & 1 & 4 & 6 \\
\hline Raised & & 1 & 3 & & & 1 & & & 1 \\
\hline Shallow & 1 & & 2 & 1 & 7 & & 1 & & 5 \\
\hline Deep & 8 & 2 & 5 & 2 & & & & 4 & 2 \\
\hline Undermined edge & 9 & 2 & 1 & 1 & & 1 & & 3 & 2 \\
\hline Tender & 8 & 3 & 1 & 3 & 6 & 1 & 1 & 4 & 4 \\
\hline Purulent & 9 & 3 & 4 & 2 & 2 & 1 & 1 & 4 & 2 \\
\hline Bubo & 2 & 1 & 8 & & & 1 & & & \\
\hline \multicolumn{10}{|l|}{ Ulcer site*: } \\
\hline Prepuce & 5 & 2 & 7 & 1 & 6 & 1 & 1 & 1 & 3 \\
\hline Penile shaft & 3 & & 2 & & & & & 1 & 4 \\
\hline Labiae & 1 & 1 & 2 & 1 & & & & & \\
\hline Other site & 4 & 1 & 4 & 1 & 3 & & & 3 & 2 \\
\hline
\end{tabular}

*Multiple ulcers were sometimes located at different sites.

$\mathrm{HD}=$ Haemophilus ducreyi, $\mathrm{DL}=$ ducreyi-like bacteria, TP = Treponema pallidum,

HSV = herpes simplex virus, VV = vaccinia virus, $\mathrm{UU}=$ Ureaplasma urealyticum, $\mathrm{PC}=$ pyogenic cocci. 
TABLE II Correlation between clinical diagnosis and microbiological findings in 46 episodes of genital ulceration in 44 patients

\begin{tabular}{|c|c|c|c|c|c|c|c|c|c|c|}
\hline \multirow{2}{*}{$\begin{array}{l}\text { Clinical } \\
\text { diagnosis }\end{array}$} & \multirow{2}{*}{$\begin{array}{l}\text { No of } \\
\text { episodes }\end{array}$} & \multirow{2}{*}{$\begin{array}{l}\text { Diagnosis } \\
\text { confirmed }\end{array}$} & \multicolumn{8}{|c|}{ Contrary microbiological findings: } \\
\hline & & & $D L$ & $T P$ & $H S V$ & $V V$ & $U U$ & $P C$ & $\therefore \quad N i l$ & Total \\
\hline $\begin{array}{l}\text { Chancroid } \\
\text { Primary syphilis }\end{array}$ & $\begin{array}{r}19 \\
9\end{array}$ & $\begin{array}{r}10 \\
9\end{array}$ & 3 & 2 & 1 & 1 & & 2 & & 9 \\
\hline Herpes simplex & 9 & 6 & & & & & & & 3 & 3 \\
\hline Pyodermia & 3 & 2 & & & & & & & 1 & 1 \\
\hline No diagnosis & 6 & 4 & & 1 & & & 1 & & & 2 \\
\hline Total & 46 & 31 & 3 & 3 & 1 & 1 & 1 & 2 & 4 & 15 \\
\hline
\end{tabular}

$\mathrm{DL}=$ ducreyi-like bacteria, $\mathrm{TP}=$ Treponema pallidum, $\mathrm{HSV}=$ herpes simplex virus, $\mathrm{VV}=$ vaccinia virus, $\mathrm{UU}=$ Ureaplasma urealyticum, PC $=$ pyogenic cocci.

like bacteria. Table III summarises the differences between them and $H$ ducreyi.

Direct Gram staining of the ulcer material identified one of the 10 patients who were culture positive, but organisms were not noted in patients with ducreyi-like bacteria. Two patients with confirmed syphilis, both with negative dark field microscopy results, yielded ducreyi-like bacteria, one in pure culture and one mixed with several anaerobic species. The ulcers of the patient with vaccinia virus infection concomitantly yielded group F streptococci and $M$ hominis. One of the seven herpes simplex viruses was found to belong to type I.

Three cases were diagnosed on clinical grounds as being genital pyodermia. Two were confirmed by the culture of Staphylococcus aureus (one) and Streptococcus pyogenes (one). The ulcer material from two other patients yielded streptococci in pure culture: Str bovis (one ) and Str agalactiae (one).

Of the six patients in whom no clinical diagnosis could be made, one had syphilis and $U$ urealyticum was isolated from the ulcer of another. In paired sera taken at the first clinic attendance and 14 days later this patient had an eightfold rise in titre of serum antibody against the autologous isolate. Genital

TABLE III Differences between Haemophilus ducreyi (HD) and ducreyi-like bacteria (DL)

\begin{tabular}{lll}
\hline & $H D$ & $D L$ \\
\hline Cells per chain in broth culture & $\geq 12$ & $\leq 8$ \\
Outer membrane present (EM) & Yes & No \\
Colony polymorphism & Yes & No \\
Acid from: & & \\
Glucose & No & Yes \\
Saccharose & No & Yes \\
$\quad$ Xylose & No & Yes \\
L-hydroxyproline aminopeptidase & No & Yes \\
Alkaline phosphatase & Yes & No \\
\hline
\end{tabular}

$\mathrm{EM}=$ electron microscope. mycoplasmas were cultured from the ulcers of six other patients: two yielded $M$ hominis, two $U$ urealyticum, and two both species. Serum from these patients did not contain detectable antibody.

Neither yeasts nor chlamydiae were isolated from any of the ulcers, and Calymmatobacterium granulomatis was not identified in the Giemsa stained smears.

\section{Discussion}

Like other workers, ${ }^{46}$ we found that the clinical picture was an unreliable tool for the aetiological diagnosis of genital ulcers. In 15 (33\%) of the 46 episodes of ulceration in our study, the clinical diagnosis did not agree with the microbiological findings (table II).

Though a false negative bacteriological result cannot be excluded, an alternative microbiological diagnosis could be made in all nine culture negative cases of chancroid. Two patients had infections with pyogenic cocci, three with ducreyi-like bacteria, and four with combinations of known ulcerating agents ( $T$ pallidum, herpes simplex virus, or vaccinia virus) with secondary invading bacteria (predominantly anaerobic species or pyogenic cocci). The role of the ducreyi-like bacteria in the pathogenesis of genital ulcers is uncertain, but our strains resembled those isolated from the ulcers of patients in north Africa by Reyman, ${ }^{17}$ who reported them in 1946 as being true H ducreyi.

The clinical diagnosis of syphilis, mainly based on the indurated characteristic of the lesion, was confirmed by the laboratory findings in all nine cases. $H$ ducrey $i$ was also isolated from one of these. In three patients with laboratory confirmed syphilis, however, an incorrect clinical diagnosis was made. Herpes simplex virus was cultured from six of the nine patients with the clinical picture of genital herpes. Because no other microbiological diagnosis could be made in the other three, their laboratory results were probably inaccurate. This is stressed by the fact that in all three 
the lesions persisted for six days or more. ${ }^{18}$

The clinical diagnosis of genital pyodermia was confirmed in two of three patients. In the third no aetiological agent could be found, which suggested that the lesion had a traumatic or herpetic origin. In two other patients whose ulcers yielded pyogenic cocci, however, the clinical picture resembled chancroid.

A microbiological diagnosis could not be made in four of six patients with atypical lesions. These ulcers probably had a traumatic origin, though genital herpes cannot be excluded. In one of the other two patients, the atypical ulcer was the primary lesion of syphilis, and the other one had some evidence of infection with $U$ urealyticum. The absence of any other aetiological agent, the eightfold rise in antibody titre, and the curative effect of treatment with erythromycin suggested that the organism had a role in the pathogenesis of the genital lesions in this patient.

In this study percentages of error in clinical diagnosis varied from 0 to nearly 50 . This emphasises the fact that doctors dealing with STD should be aware that the clinical diagnosis of genital ulcers is unreliable, especially in lesions resembling those of chancroid. Like others ${ }^{5}$ we found that direct Gram staining of ulcer material was of little value in the definitive diagnosis of chancroid. For each patient presenting with genital lesions a preliminary diagnosis based on clinical grounds should be confirmed by laboratory tests, which should include one of the recently developed selective culture media for H ducreyi. ${ }^{919}$

\section{References}

1. Mandell GL, Douglas Jr RG, Bennett JE. Principles and practice of infectious diseases. 2nd ed. New York: John Wiley, 1985.

2. King A, Nicol C, Rodin P.Venereal diseases. th ed London: Ballière Tindall, 1980.

3. Rook A, Wilkinson DS, Ebling FJG. Textbook of dermatology. 3rd ed. Oxford: Blackwell Scientific Publications, 1982.
4. Chapel T, Brown WJ, Jeffries C ,Stewart JA. The microbiological flora of penile ulcerations. J Infect Dis 1978;137:506.

5. Nzanze H, Fast MV,D Costa JL, Tukei P, Curran J, Ronald A. Genital ulcers in Kenya. British Journal of Venereal Diseases 1981;57:378-81.

6. Slazman RS ,Kraus SJ, Miller RG, Sottnek FO, Kleris GS. Chancroidal ulcers that are not chancroid. Arch Dermatol 1984;120:636-9.

7. Kinghorn GR, Hafiz S, McEntegart GM. Pathogenic microbial flora of genital ulcers in Sheffield with particular reference to herpes simplex virus and Haemophilus ducreyi. British Journal of Venereal Diseases 1982;58:377-80.

8. Philips E, Nash P. Culture media..In: Lennette EH, Balows A, Hausler Jr WJ, Shadomy HJ, eds. Manual of clinical microbiology. 4th ed. Washington DC: American Society for Microbiology, 1985:1051-92

9. Sturm AW, Zanen HC. Characteristics of Haemophilus ducreyi in culture. J Clin Microbiol 1984;19:672-4.

10. Faur YC, Weisburd MH ,Wilson ME. A new medium for the isolation of the pathogenic Neisseria (NYC medium). I. Formulation and comparisons with standard media. Health Laboratory Science 1973;10:44-54.

11. Shepard MC, Lunceford CD. Urease color test medium U-9 for the detection and identification of T-mycoplasmas in clinical material. Applied Microbiology 1970;20:539-43.

12. Purcell RH, Taylor-Robinson D, Wong D, Chanock RM. Color test for the measurement of antibody to T-strain mycoplasmas. $J$ Bacteriol 1966;92:6-12.

13. Marmion BP. Mycoplasmas: technical methods. In: Cruickshank R, Duguid JP, Marmion BP, Swain RHA, eds. Medical microbiology. 12th ed. Edinburgh: Churchill Livingstone, 1975 (vol 2):522-35.

14. Sturm AW, Zanen HC. Enzymic activity of Haemophilus ducreyi. J Med Microbiol 1984;18:181-7.

15. Cowan ST, Steel KJ. Manual for identification of medical bacteria. 2nd ed. Cambridge: Cambridge University Press, 1974.

16. Lennette EH, Balows A, Hausler Jr WJ, Shadomy HJ. Manual of clinical microbiology. 4th ed. Washington DC: American Society for Microbiology, 1985.

17. Reyman F. A study of the growth conditions of Haemophilus ducreyi. Acta Pathol Microbiol Scand 1947;24:208-12.

18. Herrmann $\mathrm{Jr}$ EC. Experiences in laboratory diagnosis of herpes simplex, varicella-zoster and vaccinia virus infections in routine medical practice. Mayo Clin Proc 1967;42:744-53.

19. Nsanze H, Plummer FA, Maggwan ABN, et al. Comparison of media for the primary isolation of Haemophilus ducreyi. Sex Transm Dis 1984;11:6-9. 